\title{
APPLICATIONS OF LASER TECHNOLOGY AND NANOPARTICLES FOR SOIL REMEDIATION BY HEAVY METALS REMOVAL
}

\section{A. E. El-Raie ${ }^{1}$, M. A. Aziz ${ }^{2}$, H. E. Hassan ${ }^{3}$ and E. Abdelsalam ${ }^{4}$ \\ ABSTRACT}

Soil is the basic natural resource needed for more than $95 \%$ of the global food and fiber production; thus it represents a basic requisite for life on earth. So, soil pollution attracts the attention of the researchers to reduce soil pollution. As a result of the irrigation by wastewaters and the use of chemical fertilizers and pesticides, the amount of heavy metals in the soil exceeds the maximum permissible limits. In the current investigation, the removal of heavy metals from soil layers $(0-15,15-30$ and 30-45 cm) in soil columns, by iron nanoparticles (Fe NPs) and iron nanoparticles deposit on the surface of silica nanoparticles $\left(\mathrm{SiO}_{2} / \mathrm{Fe}\right.$ NPs), has been studied. Fe NPs were prepared by borohydride reduction method and irradiated with $308 \mathrm{~nm}$ excimer laser pulses. The results indicated that the following points: 1) The maximum absorption of Fe NPs irradiated with $308 \mathrm{~nm}$ excimer laser pulses (50, 75 and 100 thousand pulses [tp]); found to be increased as the number of pulses increased, due to increasing of the number of particles and size reduction. The TEM photography gives good criteria about the size reduction process; 2) All sizes of $\mathrm{Fe} N \mathrm{NS}$ and $\mathrm{SiO}_{2} / \mathrm{Fe} \mathrm{NPs}$ proved to be a good technique for soil remediation in the case of $\mathrm{Pb}, \mathrm{Cd}$ and $\mathrm{Cu} ; 3$ ) Removal efficiency of heavy metals was found to vary between soil layers (0-15, 15-30 and 30-45 cm); by 84.62, 69.80 and 61.04\%, for Pb, 98.05, 83.76 and $62.14 \%$ for $\mathrm{Cd}$ and 67.58, 63.76 and 59.33\% for $\mathrm{Cu}$, respectively, with treated $50 \mathrm{tp}$. This found to be decrease as increase of clay and organic matter content; and 4) The removal process was observed to much less efficient in the case of Ni found in the soil layers $(0-15,15-30$ and $30-45 \mathrm{~cm})$ were $32.81,39.83$ and $8.53 \%$ respectively, with treated $50 \mathrm{tp}$.

Key words: Soil remediation, Fe nanoparticles, Heavy metals, Excimer laser.

1- Prof. Dr., Agric. Eng. Dep., Fac. of Agric., Cairo Univ.

2 \& 3- Assoc. Prof., Inst. of Laser Enhanced Sc. (NILES), Cairo Univ. 4- Assist. Lec., . Inst. of Laser Enhanced Sc. (NILES), Cairo Univ. 


\section{INTRODUCTION}

$\mathrm{I}$ nputs of trace elements through human activities have been increased since the last century. Both industrial and agricultural operations contribute to the elevation of trace metals in soil. The smelter-related industries often act as point sources of metals, which enter agroecosystems by dry and wet deposit or use of industrial byproducts. Use of metal-containing substances in agriculture has significantly increased to sustain crop production. Application of trace elements such as $\mathrm{Cu}, \mathrm{Zn}$, $\mathrm{Fe}, \mathrm{Mn}$, and $\mathrm{B}$ that are essential to plant growth is now common practice for correcting deficiencies in these elements (Fageria et al., 2002).

Rabie and Abd El-Sabour (1999) reported that the total $\mathrm{Pb}$ in the surface layer $(0-15 \mathrm{~cm})$ of soil irrigated with wastewater of Shebin ElQanater collector, El-Shaboura canal and Mostorod collector drain was 233, 184 and $180 \mathrm{ppm}$, respectively. While, for the soil depth of (15-30 $\mathrm{cm}$ ) was 169, 164 and 169.7 ppm, respectively.

Rabie et al. (1999) reported that the highest values of total $\mathrm{Cd}$ are observed in the surface layers $(0-15 \mathrm{~cm})$ of soil irrigated with polluted water of Shebin El-Qanater collector drain, E-Shaboura canal and Mostorod collector drains, reached 8.5, 13.0 and $7.9 \mathrm{mg} / \mathrm{kg}$, respectively. While, the total $\mathrm{Cd}$ in deepest layers $(15-30 \mathrm{~cm})$ of these soils was 2.6 , 4.0 and $7.1 \mathrm{mg} / \mathrm{kg}$, respectively. Moreover, they reported that the total amounts of $\mathrm{Cu}$ in the surface layers $(0-15 \mathrm{~cm})$ of these soils were 197.3, $106.8,112.4$ and $135.5 \mathrm{mg} / \mathrm{kg}$, respectively. While, in the soil layers (15$30 \mathrm{~cm}$ ) were $142,105,104$ and $103 \mathrm{mg} / \mathrm{kg}$, respectively.

Rashad et al. (1995) found that the normal level of total $\mathrm{Ni}$ in alluvial soils of Nile delta ranged between 21.0- 44.0 ppm (average $32.0 \mathrm{ppm}$ ). Concerning contaminated alluvial soils of Egypt, El-Sayed and Hegazy (1993) reported that the total content of $\mathrm{Ni}$ in contaminated alluvial soils of El-Fayoum Governorate ranged between 33.5 and 77.0 with an average of $55.3 \mathrm{ppm}$.

Makino et al. (2006) reported that Calcium chloride and $\mathrm{FeCl}_{3}$ were selected as soil-washing chemicals for use in Cd-contaminated paddy soils on the basis of their Cd-extraction efficiency, cost-effectiveness, and relatively low environmental impacts. 
Virkutyte et al. (2002), applied a low-level direct current (DC) across electrodes, inserted in the treated soil, to generate an electric field for removal of the contaminants. These electric fields induce the transport of heavy metals ions in soil pore water due to electromigration, as well as electroosmosis and electrophoresis (Hamed et al., 1991).

Gardea-Torresdey et al. (2004) reported that the remediation of heavy metal-contaminated sites using plants presents a promising alternative to current methodologies. The potential accumulation of Convolvulus arvensis $\mathrm{L}$. for $\mathrm{Cd}(\mathrm{II}), \mathrm{Cr}(\mathrm{VI})$, and $\mathrm{Cu}(\mathrm{II})$ was determined using an agarbased medium. The shoots of $C$. arvensis plants exposed to $20 \mathrm{mg} \mathrm{L}^{-1}$ of these heavy metals, demonstrated capability to accumulate more than $3800 \mathrm{mg}$ of $\mathrm{Cr}, 1500 \mathrm{mg}$ of $\mathrm{Cd}$, and $560 \mathrm{mg}$ of $\mathrm{Cu}$ per $\mathrm{kg}$ of dry tissue.

Zhang (2003) showed that the nanoscale iron particles represent a new generation of environmental remediation technologies that could provide cost-effective solutions to some of the most challenging environmental cleanup problems. Nanoscale iron particles have large surface areas and high surface reactivity. Modified iron nanoparticles, such as catalyzed and supported nanoparticles have been synthesized to further enhance the speed and efficiency of remediation.

Montas and Shirmohammadi (2004) reported that a mathematical model of nanoparticle transport and pollutant interaction in soil is developed and evaluated. The model includes parameters that are commonly measured independently in non-flowing systems, or with tracers, and 3 "new" parameters emanating from size exclusion and dynamic filtration of nanoparticles. Accurate simulations of nanoparticle transport and pollutant removal were produced with values of the common parameters that compared well to independent experimental measurements.

Badr and Mahmoud (2007) showed that the Ag NPs exposed to $193 \mathrm{~nm}$ pulsed excimer laser undergo photofragmentation into small particles. The TEM photographs of the Ag NPs taken before and after the irradiation with 10 thousand pulses; $3.5 \mathrm{~mJ} /$ pulse, $6 \mathrm{~ns}$ duration Excimer laser showed that the particle size was decreased from $(11 \pm 2$ to $5 \pm 1$ $\mathrm{nm})$. 
The objectives of the present investigation are:

1) Preparation of $\mathrm{Fe} \mathrm{NPs}$ via borohydride reduction method, then different sizes were obtained by irradiation with Excimer laser pulses (50, 75 and 100,000 pulse); 2) Preparation of Fe NPs deposits on the surface of Silica NPs $\left.\left(\mathrm{SiO}_{2} / \mathrm{Fe} \mathrm{NPs}\right) ; 3\right)$ Removal of heavy metals from soil layers (0-15, 15-30 and 30-45 cm); and 4) Study the effects of particles size of Fe NPs on the removal process of heavy metals.

\section{MATERIAL AND METHODS}

Soil samples: The samples were collected by using barrel auger from agricultural land; which irrigated by sewer and agricultural drain water in Khalf Allah village, Abu Keber district, El Sharkia governorate. The soil samples were taken from soil layers; surface layer $(0-15 \mathrm{~cm})$, middle layer $(15-30 \mathrm{~cm})$ and lower layer $(30-45 \mathrm{~cm})$, which containing adventitious roots of plants.

Soil columns: The columns were designed and fabricated in Laboratory of Laser Applications in Agricultural Engineering at National Institute of Laser Enhanced Sciences (NILES), Cairo University. It fabricated from poly vinyl chloride (PVC) cuboids with dimensions of $(4 \times 4 \times 50$ $\mathrm{cm})$. The elevation of the column made from transparent plastic to insure the height of each layer equal to $15 \mathrm{~cm}$ inside the column, as shown in Fig. (1). After treatment, the transparent side was removed to collect samples for analysis. The base of the column was closed using square rubber end. The treatment solution was drained from the column by small plastic hose sealed in the center of the rubber end to conical flask to maintain vertical movement of iron nanoparticles.

Digestion chemicals: Metals extractions were performed by digestion of soil samples with Hydrochloric Acid ( $\mathrm{HCl} 37 \%$, Sigma) and Nitric Acid $\left(\mathrm{HNO}_{3} 70 \%\right.$, Sigma).

Chemicals used for nanoparticles preparation: Iron and silica coated with iron nanoparticles were prepared using the following chemicals: Sodium borohydride $\left(\mathrm{NaBH}_{4}\right.$, powder $98 \%$, ALDRICH), Ferric chloride $\left(\mathrm{FeCl}_{3} \cdot 6 \mathrm{H}_{2} \mathrm{O}\right.$, granulated $99 \%$, Riedel-de Haën), Tetraethyl orthosilicate (TEOS, $\mathrm{C}_{8} \mathrm{H}_{20} \mathrm{O}_{4} \mathrm{Si}, \geq 98 \%$, Fluka), $\mathrm{HNO}_{3} 70 \%$ and Ethyl Alcohol (Ethanol, $\mathrm{C}_{2} \mathrm{H}_{6} \mathrm{O}, 96 \%$, Sigma). 
Chemicals required for calibration curves: Standards solutions of $(1000 \mu \mathrm{g} / \mathrm{mL}$, Merck-Aldrich Grade) were used to generate a calibration curve for each $\mathrm{Cd}, \mathrm{Cu}$ and $\mathrm{Pb}$.

Digestion system: Metals extraction was performed using digestion system which consists of Hotplate (BIBBY, $\left.0-450^{\circ} \mathrm{C}\right)$, Boiling flask (250 $\mathrm{mL})$ and Glass condenser $(50 \mathrm{~cm})$.

Atomic Absorption Spectrophotometer (AAS): It's an analytical equipment (Varian, SpectrAA 55), used to measure the concentration of the metal ions in the sample solution, (Fig 2). The basic components of AAS are Atomization system (spray chamber), Thermal environment (flame), Light Source (hollow cathode lamp), Monochromomater, Detector (photomultiplier) and Acquisition and recording unit.

Laser photofragmentation system: it is a system used for controlling the size of iron nanoparticles and consists of 1) Excimer laser $\mathrm{XeCl}$ (LAMBDA PHYSIK, LASERTECHIK, $3 \mathrm{mj} /$ pulse, $6 \mathrm{~ns}$ pulse width) operating at $308 \mathrm{~nm}, 2$ ) Quartz lens for focusing the laser beam on the nanoparticles solution, 3) Quartz cell $(4 \times 4 \times 4 \mathrm{~cm})$ filled with the iron nanoparticles solution, 4) Magnetic stirrer (200 rpm) for rotation the solution of the nanoparticles and 5) Small magnet, as shown in Fig. (3).

Uv-Vis. spectrophotometer: The absorption spectra of Fe NPs after exposed to the Excimer laser pulses were measured by using Uv-Vis. Spectrophotometer (Varian, Biocary 50). The exciting source is xenon lamp; in the range of 190-1100 nm; while the quartz cell was used for solutions measurement.

Transmission electron microscopy (TEM): The TEM images of Fe NPs before and after irradiated by Excimer laser pulses were taken by electron microscopy (Zeiss, $120 \mathrm{kV}$ ).

Samples treatment and preparation: 1) Soil samples of each layer were air dried and mixed thoroughly, 2)Transfer samples into the soil columns according to its depth, Fig (1), 3) Saturate the soil columns by nanoparticles (50 mL NPs mixed with $450 \mathrm{~mL}$ distilled water), 4) Collect several treated soil samples along each layer from the columns after removing the transparent side, 5)Dry the samples in oven (BINDER, $5^{\circ} \mathrm{C}$ above ambient up to $300^{\circ} \mathrm{C}$ ) at $\ldots 110^{\circ} \mathrm{C}$ for $12 \mathrm{~h}$, then ground to 
pass through a $2 \mathrm{~mm}$ sieve and 6) Store in sealed plastic bags at $>20{ }^{\circ} \mathrm{C}$ prior to analysis.

Aqua regia extraction procedure: Total metals content in the soil sample were estimated using aqua regia extraction method, following the procedure recommended by the International Organization for Standardization (ISO 11466, 1995.). Aqua regia extraction leads to the maximum soluble acid amount of metals (Kalbitz and Wennrich, 1998), with recoveries from 89 to $110 \%$ for some metals in soils and sediments (Bettinelli et al., 2000.)

Metals analysis: The extracted solution of soil samples were analyzed by flame atomic absorption spectrophotometer (AAS), where the sample solution converts into a fine mist or aerosol to be feed to the flame (airacetylene gas an oxidant/fuel combination). In the flame, a complicated process involving desolvation of the solution droplets and dissociation of the chemical compounds results in the production of gaseous atoms of the constituent elements, which could be determine by standard or calibration curve.

Construction of calibration curve: Three dilutions of standard solution were used to generate a calibration curve for each analysis, from stock standard solutions $(1000 \mu \mathrm{g} / \mathrm{mL}$ Merck-Aldrich Grade) of the analytes elements. The calibration curve was obtained by measuring the absorbance of each stander solution, and then plotting the curve of absorbance versus the corresponding concentration.

Preparation of iron nanoparticles (Fe NPs): Fe NPs were prepared chemically by reduction method of ferric ions via sodium borohydride;

$$
\mathrm{Fe}\left(\mathrm{H}_{2} \mathrm{O}\right)_{6}^{3+}+3 \mathrm{BH}_{4}^{-}+3 \mathrm{H}_{2} \mathrm{O} \rightarrow \mathrm{Fe}^{0}+3 \mathrm{~B}(\mathrm{OH})_{3}+10.5 \mathrm{H}_{2} \quad \text { (Eq.1) }
$$

$(0.2 \mathrm{M}) \mathrm{NaBH}_{4}$ was added drop-wise under vigorously stirring into $(0.05$ M) ferric chloride solution $\left(\mathrm{FeCl}_{3} \cdot 6 \mathrm{H}_{2} \mathrm{O}\right)$, till the mixture be colorless just before the aggregation of the iron particles. The high concentration difference between the two solutions leads to the formation of iron nanoparticles (Wang and Zhang, 1997), according to the following reaction: 
Preparation of silica nanoparticles $\left(\mathrm{SiO}_{2} \mathrm{NPs}\right)$ : Silica nanoparticles $\left(\mathrm{SiO}_{2} \mathrm{NPs}\right)$ were prepared, using tetraethyl orthosilicate (TEOS) and $\mathrm{HNO}_{3}$ as an acid catalyst (Jiang et al., 2004). TEOS and ethanol with volumes of $10 \mathrm{~mL}$ were mixed together; the resulting mixture was dropped in $60 \mathrm{~mL} 0.1 \mathrm{~N} \mathrm{HNO}_{3}$ solution, the final mixture was stirred for $8 \mathrm{~h}$ at $60{ }^{\circ} \mathrm{C}$ for complete hydrolysis of TEOS to $\mathrm{SiO}_{2} \mathrm{NPs}$. The concentration of $\mathrm{SiO}_{2} \mathrm{NPs}$ solution was found to be $(30 \mathrm{~g} / \mathrm{L})$ after it was completed to $100 \mathrm{~mL}$ by distilled water.

Preparation of Fe NPs adsorbed on the surface of $\mathrm{SiO}_{2}$ N Ps: Fe NPs deposited on the surface of $\mathrm{SiO}_{2} \mathrm{NPs}$ was prepared by mixing $0.676 \mathrm{~g}$ of $\mathrm{FeCl}_{3}$ with $50 \mathrm{~mL} \mathrm{SiO}_{2} \mathrm{NPs}$ under vigorously stirring for $5 \mathrm{~min}$. Then, $0.2 \mathrm{M} \mathrm{NaBH} 4$ was added drop-wise to the solution (Kamat et al., 2002).

Photofragmentation of Fe NPs: Although, the chemical methods are the simplest methods used for preparation of nanoparticles (e.g. metallic), the optimum method used here for preparation of controllable size is the simple chemical method, where particle size is reduced and particle size distribution is decreased (Badr et al., 2006). Fe NPs solution exposed to $308 \mathrm{~nm}$ excimer laser pulses; the particles undergo photofragmentation into small nanofragments. The quartz cell filled with the solution of $\mathrm{Fe}$ NPs and the small magnet is placed inside, then the magnetic stirrer is operated at (200 rpm). Finally, the cell is exposed to the Excimer laser, and the cell is bombarded by certain number of pulses (50,75 and 100 thousand pulse [tp]) at repetition rate $(200 \mathrm{~Hz})$.

Uv-Vis. spectra of Fe NPs: The absorption spectra of Fe NPs samples un-irradiated and after exposed to the Excimer laser (50, 100 thousand pulses), were obtained to study the effect of Excimer laser on the particle size of iron nanoparticles.

Determine the size of Fe NPs: The average diameters and size distributions of Fe NPs samples after irradiated by Excimer laser were calculated by counting over 150 particles from the enlarged TEM (Zeiss, $120 \mathrm{kV}$ ) photography. The samples were prepared by putting a drop of solution on a cupper carbon grid and setting the drop dry completely in a desicrator (Badr and Mahmoud, 2005). 


\section{RESULTS AND DISCUSSION}

\section{Photofragmentation of iron nanoparticles (Fe NPs)}

Accordingly in the present work, the iron nanoparticles (Fe NPs) were similarly subjected to 50, 75 and 100 thousand pulses of $(\mathrm{XeCl})$ Excimer laser ( $3 \mathrm{~mJ} /$ pulse, $6 \mathrm{~ns}$ pulse width, $200 \mathrm{~Hz}$ ) operating at $308 \mathrm{~nm}$. The same results were obtained, Fe NPs has an absorption peak corresponding to the surface Plasmon oscillation; the position of this peak was found to depend on their particle size (Badr et al., 2006). Fig. (4) shows the absorption spectra of Fe NPs before and after irradiation with 50,100 thousand pulses of $3 \mathrm{mj} /$ pulse excimer laser. A blue shift was observed by increasing the number of pulses which are in the order (350, 345 and $341 \mathrm{~nm})$. Moreover, the peaks intensities were found to be increased; due to increasing of the number of particles, resulting from the photofragmentation. The $\mathrm{FeCl}_{3}$ has no characteristic peak in the measurement area.

\section{Effect of the number of laser pulses on the size of Fe NPs:}

The samples of Fe NPs were exposed to laser pulses; $3 \mathrm{~mJ} /$ pulse, $308 \mathrm{~nm}$ and $6 \mathrm{~ns}$ duration excimer laser. Absorption spectra after irradiation were compared with the corresponding untreated samples. In addition, the TEM photography supports the optical measurements. The blue shift and the increasing of the peek intensities were observed due to the increasing of the laser pulses. The TEM images were found to support the size reduction idea as shown in Figs. (5). The particle size distribution as well as the particle size of un-irradiated Fe NPs was $50 \pm 5 \mathrm{~nm}$. While, the particles size was decreased due to irradiation by 50, 75 and 100,000 pulses to $40 \pm 2,35 \pm 2$ and $30 \pm 1 \mathrm{~nm}$, respectively. To summarize, the particles size of Fe NPs were decreased as the number of the laser pulses increased.

On the other hand, the $\mathrm{SiO}_{2}$ NPs showed a spherical shape with large distribution $(15 \pm 8 \mathrm{~nm})$ Badr et al., 2008. While in case of Fe NPs deposited on the surface of $\mathrm{SiO}_{2}$ NPs the particles size was approximately $(25 \pm 5 \mathrm{~nm})$ due to the appearance of Fe NPs on the surface of $\mathrm{SiO}_{2}$ NPs (Fig. 5(E)). 


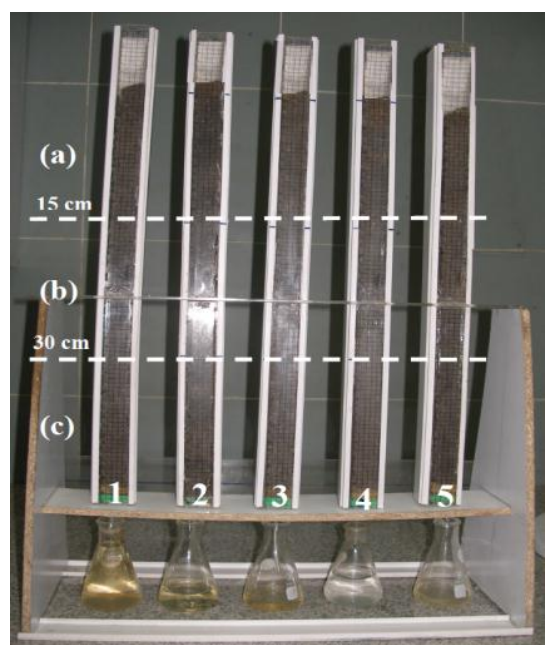

Fig. (1): Soil columns containing samples treated with nanoparticles (a) surface layer $(0-15 \mathrm{~cm})$, (b) middle layer $(15-30 \mathrm{~cm})$ and (c) lower layer $(30-45 \mathrm{~cm})$.

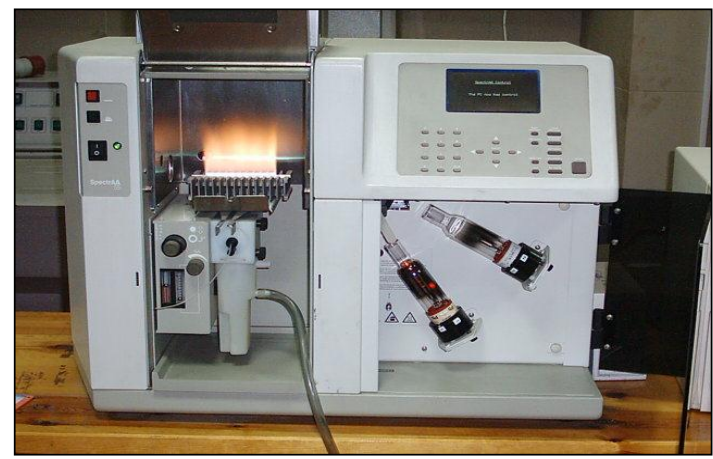

Fig. (2): Atomic Absorption Spectrophotometer (Varian, SpectrAA 55)

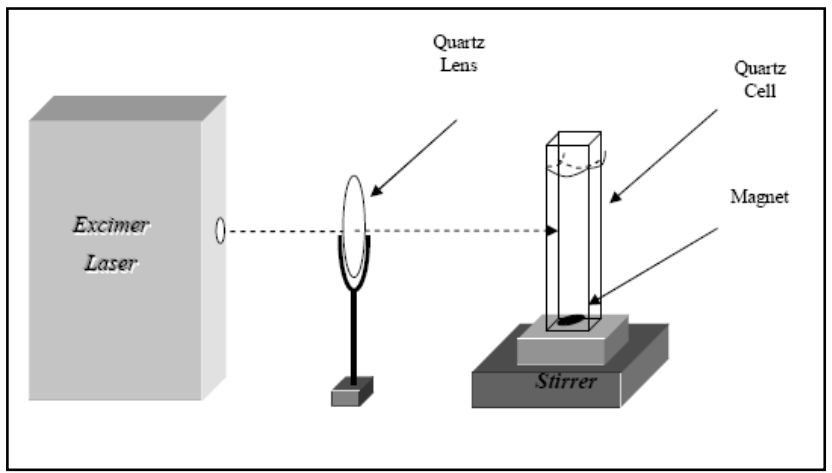

Fig. (3): The setup used in photo fragmentation of Fe NPs 


\section{Characterization of soil sample:}

The surface layer $(0-15 \mathrm{~cm})$ is the most important layer; because most of the top plant roots $(70 \%)$ supply $57-65 \%$ of plant water requirements from it; such as wheat, barley and maze. furthermore, it receives all precipitates from the atmosphere, fertilizers and pesticide. In comparison of the controlled values and the maximum permissible limits (MPL) for each metal, the concentrations of the metals ions present in this layer are exceed than that MPL except for Fe and Mn ions as shown in Fig. (7). Therefore, $\mathrm{Fe}$ nanoparticles can be used for soil remediation if the concentration of $\mathrm{Fe}$ ions is not exceeds MPL. To characterize soil sample, physical and chemical properties were obtained to different soil layers of the control, as well as heavy metals content. The soil texture of the surface layer (0-15) was sandy, while the other two layers were sandy clay. The percentage of organic matter (O.M.) in the surface layer was lower than middle and lower layers, as shown in Table (1).

Table (1): Some physical and chemical properties and heavy metals content of different soil layers.

\begin{tabular}{|l|c|c|c|}
\hline \multicolumn{1}{|c|}{ Soil layers } & $0-15 \mathrm{~cm}$ & $15-30 \mathrm{~cm}$ & $30-45 \mathrm{~cm}$ \\
\hline Coil properties & & & \\
\hline F. Sand (2-0.2 mm) & 7.9 & 43.9 & 42.3 \\
\hline Silt (O.02-0.002 mm) & 21.2 & 14.3 & 15.7 \\
\hline Clay (< 0.002 mm) & 19.3 & 25.1 & 21.1 \\
\hline Texture Class & Sandy & Sandy Clay & Sandy Clay \\
\hline pH & 7.20 & 7.32 & 7.41 \\
\hline EC (dS/m) & 0.80 & 0.48 & 0.45 \\
\hline Organic Matter (\%) & 1.44 & 1.85 & 1.50 \\
\hline CaCO, $\%)$ & 5.0 & - & - \\
\hline Cd (ppm) & 52.74 & 97.9 & 86.1 \\
\hline Pb (ppm) & 129.1 & 261.9 & 217.9 \\
\hline Cu (ppm) & 90.44 & 170 & 149 \\
\hline Co (ppm) & 24.89 & 35.7 & 43.9 \\
\hline Ni (ppm) & 101.8 & 236 & 211 \\
\hline Mn (ppm) & 384.1 & 1542 & 1278 \\
\hline
\end{tabular}




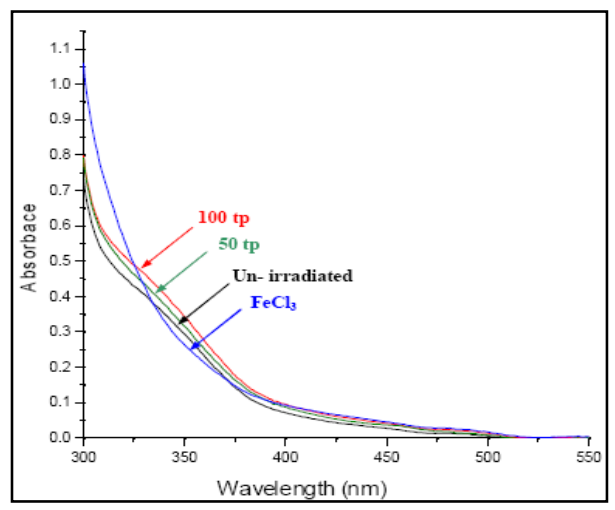

Fig. (4): The absorption spectra of Fe NPs samples after exposed to 50 and 100 thousand pluses of Excimer laser, un-irradiated and ferric chloride solution $\left(\mathrm{FeCl}_{3}\right)$.
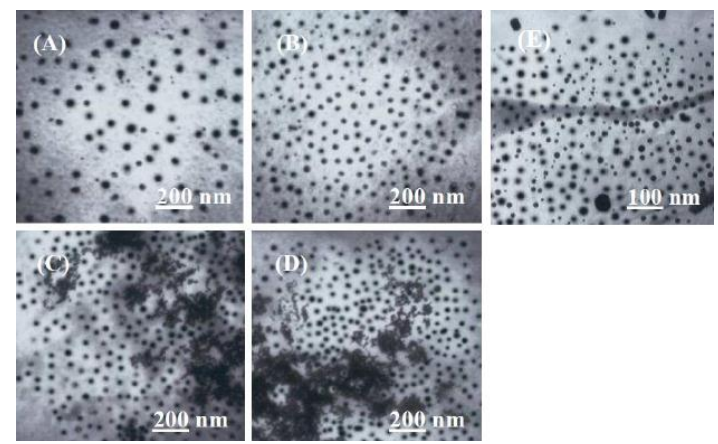

Figs.(5): The TEM images of Fe NPs; (A) Un-irradiated, (B) irradiated by 50,000 pulses, (C) irradiated by 75,000 pulses, (D) irradiated by 100,000 pulses of excimer laser and (E) Fe NPs deposit on the surface of $\mathrm{SiO} 2 \mathrm{NPs}$.

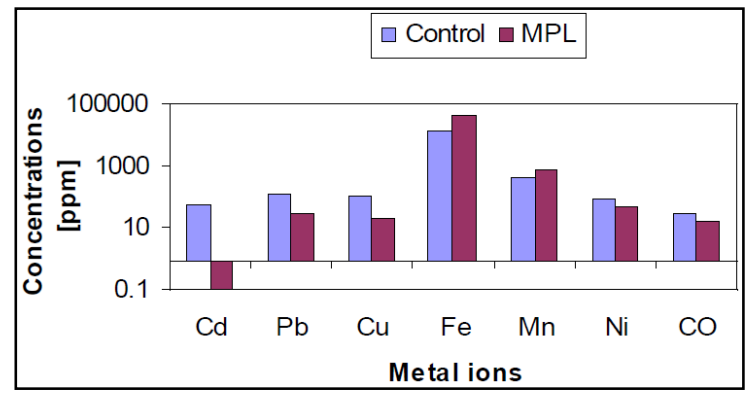

Fig. (7): The concentration of metal ions in the surface layer $(0-15 \mathrm{~cm})$ compared with maximum permissible limits (MPL). 


\section{The concentration of heavy metals in different soil layers after treatments:}

The total metals content in soil layers (0-15, 15-30 and 30-45 cm) was determined before and after treatment by iron nanoparticles (Fe NPs) prepared by the chemical method, Fe NPs after irradiation with $(50,75$, 100 thousands pluses [tp]); $308 \mathrm{~nm} 2.5 \mathrm{mj} /$ pulse excimer laser. Also, another treatment was carried out by Fe NPs deposit on the surface of silica nanoparticles $\mathrm{SiO}_{2} / \mathrm{Fe} \mathrm{NPs}$.

\subsection{Lead:}

\section{The surface layer:}

Because of the toxic effects of lead and to indicate the efficiency of the proposed technique in the present work for soil remediation; a pilot study was carried out by enriching the surface layer of the soil with $\mathrm{Pb}$ and by measuring the concentration before and after treatment with Fe NPs, an astonishing result was obtained. The concentration of $\mathrm{Pb}$ drop from 2975 ppm to $28.45 \mathrm{ppm}$ after treatment by Fe NPs. i.e, the proposed technique for soil remediation reduced the amount of $\mathrm{Pb}$ to less $1 \%$ of its value before remediation. This might give an idea about the efficiency of this mechanism. The total content of lead $(\mathrm{Pb})$ in the surface layer $(0-15 \mathrm{~cm})$ before the treatment by nanoparticles (control) was found to be 129.1 ppm. While the total content of lead was decreased to 16.78, 19.86, 51.80 and $15.53 \mathrm{ppm}$, after treatment by Fe NPs un-irradiated and irradiated with (50, 75 and 100 thousands pluses [tp]), respectively. Also, the treatment by silicon oxide nanoparticles $\left(\mathrm{SiO}_{2} \mathrm{NPs}\right)$ coated with Fe NPs $\left(\mathrm{SiO}_{2} / \mathrm{Fe} \mathrm{NPs}\right)$ decreased the untreated value to $21.36 \mathrm{ppm}$ as shown in the Fig. (8).

\section{The middle layer:}

Fig. (8) Showed that the total $\mathrm{Pb}$ content present in soil depth $(15-30 \mathrm{~cm})$. It was noticed that, the highest concentration of $\mathrm{Pb}$ was found to be 261.9 ppm before treatment (control). After the treatment by Fe NPs unirradiated and irradiated with $(50,75$ and 100 tp) this amount was decreased to $91.8,79.1,86.5$ and $86.6 \mathrm{ppm}$, respectively. Also, the treatment by silicon oxide nanoparticles $\left(\mathrm{SiO}_{2} \mathrm{NPs}\right)$ coated with Fe NPs $\left(\mathrm{SiO}_{2} / \mathrm{Fe} \mathrm{NPs}\right)$ decreased the untreated value to $70.1 \mathrm{ppm}$. 


\section{The lower layer:}

Fig. (8) Represents the total $\mathrm{Pb}$ content found in soil depth $(30-45 \mathrm{~cm})$. It was noticed that, the highest concentration of $\mathrm{Pb}$ was found to be 217.9 ppm before treatment (control). After the treatment by Fe NPs unirradiated and irradiated with (50,75 and 100 tp) this amount decreased to $71.6,84.9,82.3$ and $93.4 \mathrm{ppm}$, respectively. Also, the treatment by $\left(\mathrm{SiO}_{2} / \mathrm{Fe} \mathrm{NPs}\right)$ decreased the untreated value to $102.3 \mathrm{ppm}$.

\section{The effect of treatment on lead concentration:}

According to the obtained results, it is clearly seen that all sizes of nanoparticles used succeeded in removing high percentage of $\mathrm{Pb}$ from soil layers to meet the maximum permissible limit of $\mathrm{Pb}$. Moreover, as indicated in Fig. (9), the effect of treatments on $\mathrm{Pb}$ concentration in the surface layer is more than other layers except with the treatment by Fe NPs irradiated with $75 \mathrm{tp}$, however, the removal percentage in middle and lower layers was increased with this treatment. By comparing the treatments effect in the surface layer, the highest removal \% was 87.97 with the treatment by Fe NPs irradiated with 100 tp. While, among all treatments the best effect of the $\mathrm{Pb}$ removal with the treatment by the small size of Fe NPs (100 tp) and $\mathrm{SiO}_{2} / \mathrm{Fe}$ NPs.

\subsection{Cadmium:}

\section{The surface layer:}

Fig.(10) showed that total Cadmium (Cd) content present in the surface layer $(0-15 \mathrm{~cm})$ was $52.74 \mathrm{ppm}$ as a control value. Moreover the treatment by Fe NPs un-irradiated and irradiated with (50, 75 and 100 tp) decreased this amount to $0.25,1.03,0.15$ and $2.39 \mathrm{ppm}$, respectively. While, the treatment by $\left(\mathrm{SiO}_{2} / \mathrm{Fe} \mathrm{NPs}\right)$ decreased the control value by large amount to $0.09 \mathrm{ppm}$.

\section{The middle layer:}

The concentration of total Cd present in the middle layer $(15-30 \mathrm{~cm})$ was $97.9 \mathrm{ppm}$ as a control value. Moreover, this amount decreased to 32.8, 15.9 , 




Fig. (8): The total content of $\mathrm{Pb}$ in soil layers $(0-15,15-30$ and $30-45 \mathrm{~cm})$ before and after treatment by nanoparticles.

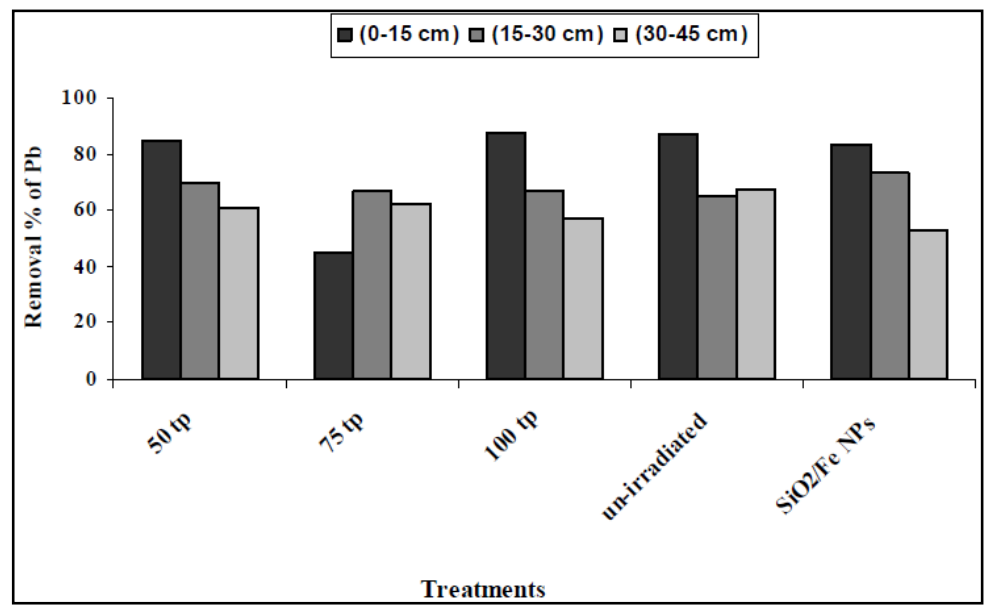

Fig. (9): The removal percent of $\mathrm{Pb}$ from different soil layers after treatment by $\mathrm{Fe}$ NPs and $\mathrm{SiO} 2 / \mathrm{Fe}$ NPs. 
20.6 and $28.1 \mathrm{ppm}$, after the treatment by Fe NPs un-irradiated and irradiated with (50, 75 and $100 \mathrm{tp})$, respectively. While, the treatment by $\left(\mathrm{SiO}_{2} / \mathrm{Fe} \mathrm{NPs}\right.$ ) decreased the control value to $39.5 \mathrm{ppm}$ as shown in Fig. (10).

\section{The lower layer:}

As shown in Fig. (10) the concentration of total Cd present in the lower layer $(30-45 \mathrm{~cm})$ was $86.1 \mathrm{ppm}$ as a control value. While, this amount decreased to 36.1, 32.6, 37.5 and 39.4 ppm, after the treatment by Fe NPs un-irradiated and irradiated with $(50,75,100 \mathrm{tp})$, respectively. Also, the treatment by $\left(\mathrm{SiO}_{2} / \mathrm{Fe} \mathrm{NPs}\right)$ decreased the control value to $33.7 \mathrm{ppm}$.

\section{The effect of treatment on cadmium concentration:}

The obtained results showed that, all size of iron nanoparticles succeeded in removing high percentage of $\mathrm{Cd}$ from different soil layers. Fig. (11) indicated that the removal \% of Cd form surface layer was over $95 \%$ for all treatments; however the highest removal \% with $\mathrm{SiO}_{2} / \mathrm{Fe} \mathrm{NPs}$ was $99.83 \%$. By comparing the treatment effects in the middle layer; the highest removal \% was 83.76 with Fe NPs irradiated by 50 tp. also, in the lower layer the highest percent of $\mathrm{Cd}$ removal was $62.14 \%$. The treatment by Fe NPs irradiated by 50 tp have greater effect on $\mathrm{Cd}$ removal from soil layers although the high concentration of the control.

\subsection{Copper:}

\section{The surface layer:}

As shown in Fig. (12) the total content of copper $(\mathrm{Cu})$ at the soil depth $(0-15 \mathrm{~cm})$ was $90.44 \mathrm{ppm}$ as control value. This value was decreased to 36.02, 29.32, 29.99 and $33.28 \mathrm{ppm}$, by the treatment of Fe NPs unirradiated and irradiated with (50, 75 and $100 \mathrm{tp})$, respectively. Also, the treatment by $\left(\mathrm{SiO}_{2} / \mathrm{Fe} \mathrm{NPs}\right)$ was decreased the control value to be 33.73 ppm.

\section{The middle layer:}

The total $\mathrm{Cu}$ content at the soil depth $(15-30 \mathrm{~cm})$ was $170 \mathrm{ppm}$ as control value. This value was decreased by the treatment of Fe NPs un-irradiated and irradiated with (50, 75 and 100 tp) to 70.5, 61.6, 71.4 and $72.4 \mathrm{ppm}$, 
BIOLOGICAL ENGINEERING 


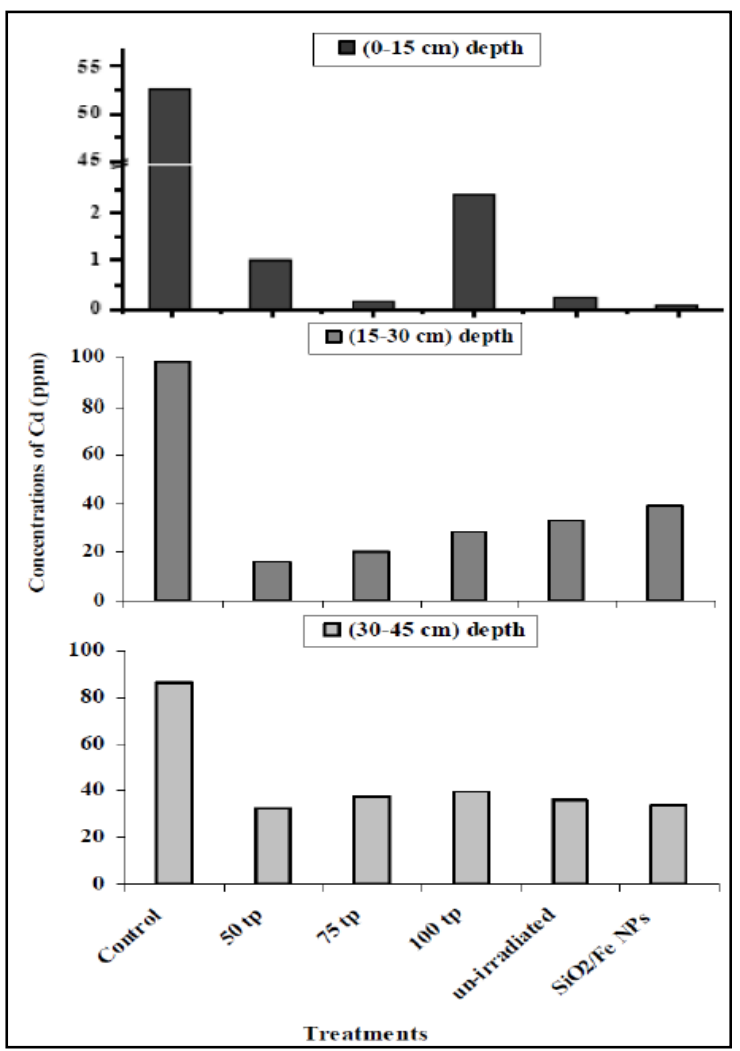

Fig. (10): The total content of Cd in soil layers (0-15, 15-30 and 30-45 $\mathrm{cm})$ before and after treatment by nanoparticles.

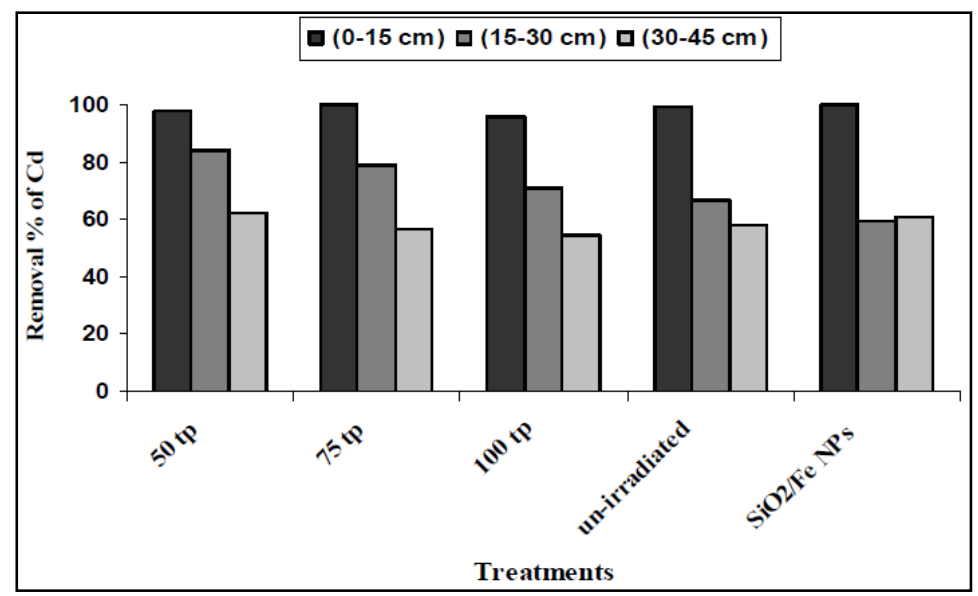

Fig. (11): The removal percent of $\mathrm{Cd}$ from different soil layers after treatment by $\mathrm{Fe} \mathrm{NPs}$ and $\mathrm{SiO} 2 / \mathrm{Fe} \mathrm{NPs}$. 
respectively, while the treatment by $\left(\mathrm{SiO}_{2} / \mathrm{Fe} \mathrm{NPs}\right)$ was decreased to be 63.5 ppm as shown in Fig. (12).

\section{The lower layer:}

Fig. (12) represents the total $\mathrm{Cu}$ content found in soil layer $(30-45 \mathrm{~cm})$. The control value of $\mathrm{Cu}$ was $149 \mathrm{ppm}$. This value was decreased by the treatment of Fe NPs un-irradiated and irradiated with (50, 75 and 100 tp) to $62.4,60.6,60.5$ and $69.5 \mathrm{ppm}$, respectively. Also, the treatment by ( $\mathrm{SiO} 2 / \mathrm{Fe} \mathrm{NPs}$ ) was decreased the control value to be $69.8 \mathrm{ppm}$.

\section{The effect of treatment on copper concentration:}

According to the results of treatment by nanoparticles, all size of iron nanoparticles succeeded in removing over $53 \%$ of $\mathrm{Cu}$ concentration from soil layers. As shown in Fig. (13) the removal percentage of $\mathrm{Cu}$ from the soil layers was almost the same for all treatments. The highest ones was $67.58,63.76$ and $59.33 \%$ for surface, middle and lower layers, respectively, by the treatment of Fe NPs irradiated by $50 \mathrm{tp}$.

\subsection{Nickel:}

\section{The surface layer:}

The total nickel $(\mathrm{Ni})$ content present in the surface layer $(0-15 \mathrm{~cm})$ was found to be $101.8 \mathrm{ppm}$ before treatment by nanoparticles. Moreover the treatment by Fe NPs un-irradiated and irradiated with (50, 75, 100 tp) decreased this amount to 59.5, 68.4, 76.2 and $88.7 \mathrm{ppm}$, respectively. Also, the treatment by $\left(\mathrm{SiO}_{2} / \mathrm{Fe} \mathrm{NPs}\right)$ decreased the untreated value to $71.2 \mathrm{ppm}$ as shown in Fig. (14).

\section{The middle layer:}

The total Ni content present in the middle layer $(15-30 \mathrm{~cm})$ was found to be $236 \mathrm{ppm}$ before the treatment by nanoparticles. Moreover, the treatment by Fe NPs un-irradiated and irradiated with (50, 75 and 100 tp) decreased this amount to 220,142, 122 and 141 ppm, respectively. Also, the treatment by $\left(\mathrm{SiO}_{2} / \mathrm{Fe} \mathrm{NPs}\right)$ decreased the untreated value to 128 ppm as shown in Fig. (14). 


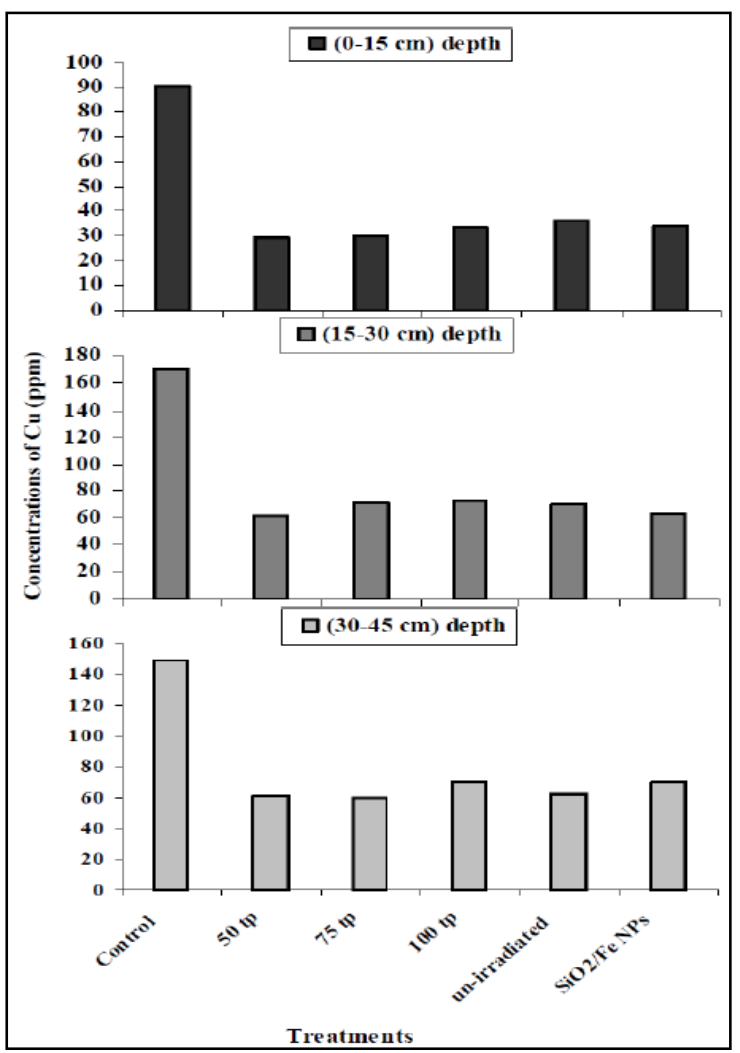

Fig. (12): The total content of $\mathrm{Cu}$ in soil layers $(0-15,15-30$ and 30-45 $\mathrm{cm})$ before and after treatment by nanoparticles.

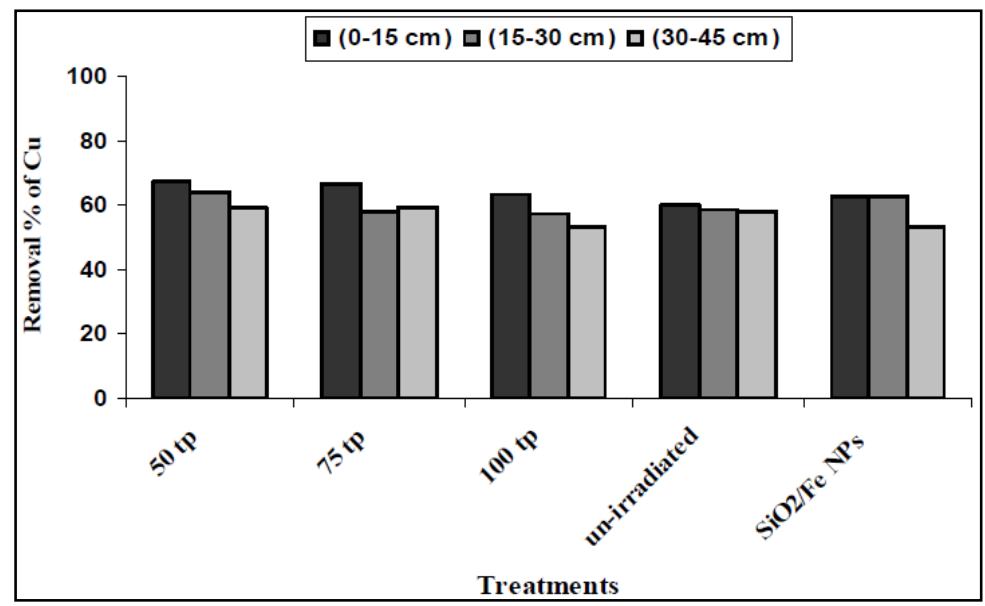

Fig. (13): The removal percent of $\mathrm{Cu}$ from different soil layers after treatment by $\mathrm{Fe}$ NPs and $\mathrm{SiO} 2 / \mathrm{Fe}$ NPs. 


\section{The lower layer:}

The total $\mathrm{Ni}$ content present in the lower layer $(30-45 \mathrm{~cm})$ was found to be $211 \mathrm{ppm}$ before treatment. After the treatment by Fe NPs un-irradiated and irradiated with (50, 75 and 100 tp), this amount decreased to 97, 193, 155 and 138 ppm, respectively. Also, the treatment by (SiO2 / Fe NPs) decreased the untreated value to $155 \mathrm{ppm}$, as shown in Fig. (14).

\section{The effect of treatment on nickel concentration:}

According to the given here data, it is clearly seen that all size of Fe NPs and $\mathrm{SiO}_{2} / \mathrm{Fe} \mathrm{NPs}$ could produce slight removal of $\mathrm{Ni}$ from soil first layers, then the removal efficiency increased in the lower layer by 82.61 $\%$ in the case of un-irradiated Fe NPs. While, the highest removal percentage in the middle layer was $48.31 \%$ in the case of Fe NPs irradiated by $100 \mathrm{tp}$. It is also indicated that the smallest size of Fe NPs (irradiated with 100tp) removed $\mathrm{Ni}$ from the middle and lower layers more than the surface layer, because the small size will move faster through the surface layer, where the $\%$ of $\mathrm{Ni}$ removal was $12.87,40.25$ and $47.10 \%$, respectively. The removal $\%$ of $\mathrm{Ni}$ with the treatment by $\mathrm{SiO}_{2} / \mathrm{Fe}$ NPs was increased with soil depth by $30.06,45.76$ and $57.73 \%$, respectively, as shown in Fig. (15).

\section{The Reduction Adsorption Mechanism of Nanoparticles:}

The suggested mechanism for the soil remediation by Fe NPs involves concerted adsorption of metal ions on the surface of nanoparticles and oxidation-reduction reaction between the iron atoms and the adsorbed ions, as shown in Fig. (16). Each iron atom supplies the metal ion by two electrons and reduced it to the corresponding metal and the ferrous ion will produced, the formed metal adsorbed on the surface of Fe NPs as given in equations (2) and (3). Moreover, the adsorbed ions could have a stander reduction potential higher than the stander reduction potential of iron (-0.44 V, $298 \mathrm{k}) \mathbf{L i}$ and Zhang, 2006. Table (2) represents the stander reduction potentials of the target metal ions. 


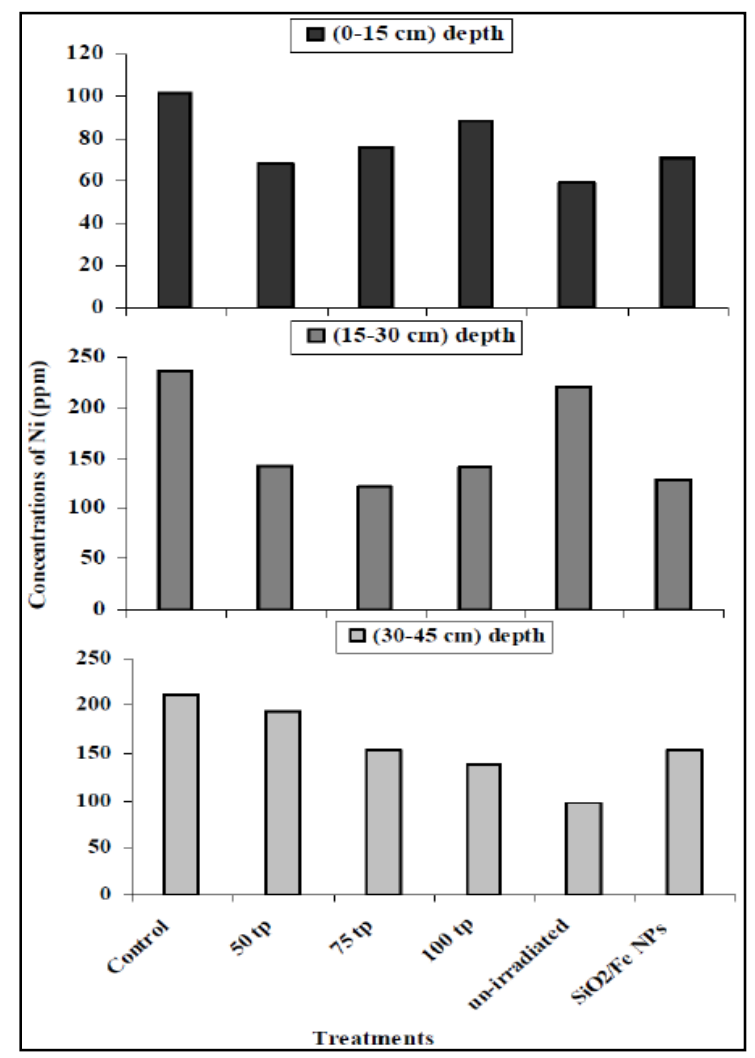

Fig. (14): The total content of Ni in soil layers (0-15, 15-30 and 30-45 $\mathrm{cm}$ ) before and after treatment by nanoparticles.

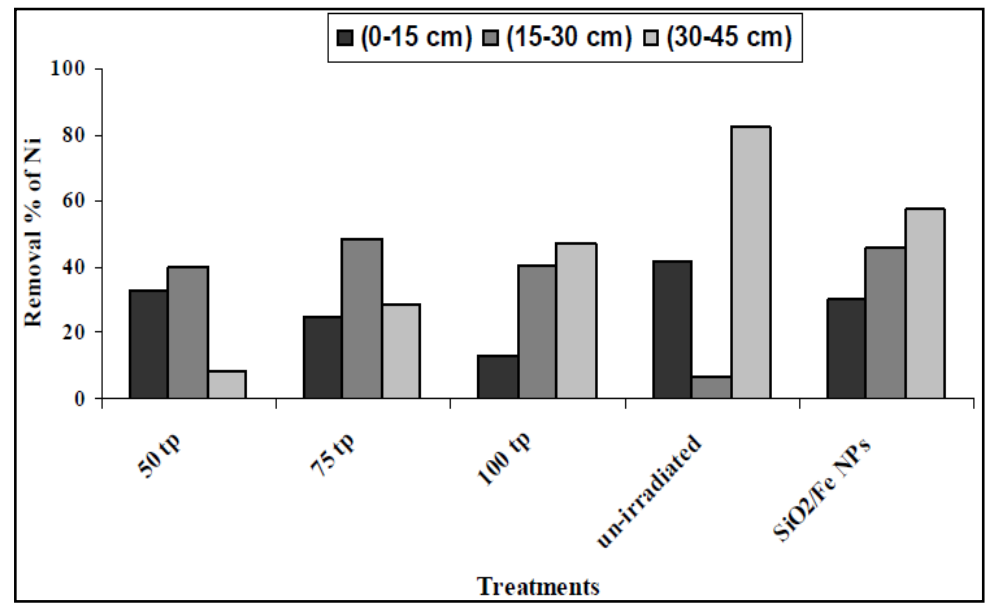

Fig. (15): The removal percent of Ni from different soil layers after treatment by $\mathrm{Fe}$ NPs and $\mathrm{SiO} 2 / \mathrm{Fe}$ NPs. 


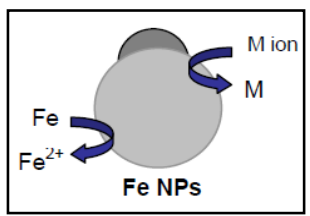

Fig. (16): Mechanism of remediation of metal ions by Fe NPs.

$$
\begin{aligned}
& \mathrm{Fe} \longrightarrow \mathrm{Fe}^{2+}+2 e \\
& \mathrm{M} \text { ion }+2 e \longrightarrow M
\end{aligned}
$$

(Eq. 3)

Table (2): The stander reduction potentials of the target metal ions.

\begin{tabular}{|c|c|}
\hline Metal ions & Stander Reduction Potential $(\mathrm{V}, 298 \mathrm{k})$ \\
\hline $\mathrm{Cd}^{2+}$ & -0.4 \\
\hline $\mathrm{Ni}^{2+}$ & -0.25 \\
\hline $\mathrm{Pb}^{2+}$ & -0.13 \\
\hline $\mathrm{Cu}^{2+}$ & 0.34 \\
\hline
\end{tabular}

\section{The Effect of Particle Size on Heavy Metals Removal:}

It was noticed that from the obtained results, iron nanoparticles (i.e. 20$50 \mathrm{~nm}$ ), have the ability to remove some heavy metals from soil layers, as well as iron deposit on the surface of silica nanoparticles. But on the other hand, the effect of particles size of iron nanoparticles showed a different removal effects. This observation might refer to the percent of organic matter, calcium carbonate and $\mathrm{pH}$ of the soil.

\section{CONCULSION}

The main conclusion of the present work can be summarized as follows:

1. The maximum absorption of Fe NPs irradiated with $308 \mathrm{~nm}$ excimer laser pulses (50, 75 and 100 thousand pulses [tp]); found to be increased as the number of pulses increased, due to increasing of the number of particles and size reduction. The TEM photography gives good criteria about the size reduction process.

2. All sizes of $\mathrm{Fe} \mathrm{NPs}$ and $\mathrm{SiO}_{2} / \mathrm{Fe} \mathrm{NPs}$ proved to be a good technique for soil remediation in the case of $\mathrm{Pb}, \mathrm{Cd}$ and $\mathrm{Cu}$. 
3. Removal efficiency of heavy metals was found to vary between soil layers $(0-15,15-30$ and $30-45 \mathrm{~cm})$; by $84.62,69.80$ and $61.04 \%$, for $\mathrm{Pb}, 98.05,83.76$ and $62.14 \%$ for $\mathrm{Cd}$ and $67.58,63.76$ and $59.33 \%$ for $\mathrm{Cu}$, respectively, with treated $50 \mathrm{tp}$. This found to be decrease as increase of clay and organic matter content.

4. The removal process was observed to much less efficient in the case of $\mathrm{Ni}$ found in the soil layers $(0-15,15-30$ and $30-45 \mathrm{~cm})$ were 32.81 , 39.83 and $8.53 \%$ respectively, with treated 50 tp.

Acknowledgement: We would like to express our deepest gratitude and thanks to Prof. Dr. Yehia Badr, Professor of Laser Physics, Former Dean of National Institute of Laser Enhanced Sciences, and Head of Laser Interaction with Matter and Laser Systems Departments, Cairo University, for providing all the facilities during carrying out this study and for his valuable advice.

\section{REFFERANCES}

\section{Abdel-Sabour, M. F.; F.M. Abdou; I.M. Elwan and Y.J. Al-Salama.} 2002. Chromium fractions changes compared with total-Cr as determined by neutron activation analysis technique. Sixth Radiation Physics Conference, October 27-30, 2002, Assiut, Egypt.

Alwan, I.; M.A. Rizk and M. F. Abdel-Sabour. 2002. Effect of irrigation with wastewater on $\mathrm{Zn}$ fractions in some contaminated soils in Egypt. Egypt. J. Appl. Sci. 17(10): 850-864.

Badr,Y.; M.G. Abd El-Wahed and M.A. Mahmoud. 2006. On $308 \mathrm{~nm}$ photofragmentation of the silver nanoparticles. Applied Surface Science. 253: 2502-2507.

Badr Y. and M.A. Mahmoud. 2007. Excimer laser photofragmentation of metallic nanoparticles. Physics Letters A. 370: 158-161.

Badr,Y. M.G. Abd El-Wahed and M.A. Mahmoud. 2008. Photocatalytic degradation of methyl red dye by silica nanoparticles. Journal of Hazardous Materials 154: 245-253.

Bettinelli, M.; G.M. Beone; S. Spezia and C. Baffi. 2000. Determination of heavy metals in soils and sediments by microwave- 
assisted digestion and inductively coupled plasma optical emission spectrometry analysis. Analytica Chimica Acta. 424 (2)289-296.

El-Sayed, E.A. and M.N. Hegazy. 1993. Total contents and extractable amounts of $\mathrm{Cd}, \mathrm{Co}, \mathrm{Cr}$ and $\mathrm{Ni}$ in some soils of El-Fayoum Governorate. J. of Agric. Resh. and Develop. 7:46-56.

Fageria, N.K.; V.C. Baligar and R.B. Clark. 2002. Micronutrients in crop production. Adv. Agron. 77:185-268.

Gardea-Torresdey, J.L.; J.R. Peralta-Videa;M. Montes; G. de la Rosa and B. Corral-Diaz. 2004. Bioaccumulation of cadmium, chromium and copper by Convolvulus arvensis L.: impact on plant growth and uptake of nutritional elements. Bioresource Technol. 92: 229-235.

Hamed, J.; Y.B. Acar and R.J. Gale. 1991. $\mathrm{Pb}$ (II) removal from kaolinite using electrokinetics. J. Geotech. Eng. 117: 241-271.

ISO 11466, 1995. Soil quality, Extraction of Trace Elements Soluble in Aqua Regia.

Jiang, Z.; C. Liu and Y. Liu. 2004. Formation of silver nanoparticles in an acid-catalyzed silica colloidal solution. Appl. Surf. Sci. 233: 135140.

Kalbitz, K. and R. Wennrich. 1998. Mobilization of heavy metals and arsenic in polluted wetland soils and its dependence on dissolved organic matter. Sci. Total Environ. 209(1):27-39.

Kamat, P.V.; M. Flumiani and A. Dawson. 2002. Metal-metal and metal-semiconductor composite nanoclusters. Colloids Surf. A 202: 269-279.

Li, X. and W. Zhang. 2006. Iron nanoparticles: the core-shell structure and unique properties for $\mathrm{Ni}(\mathrm{ii})$ sequestration. Langmuir. 22: 46384642

Makino, T.; K. Sugahara; Y. Sakurai; H. Takano; T. Kamiya; K. Sasaki; T. Itou and N. Sekiya. 2006. Remediation of cadmium contamination in paddy soils by washing with chemicals: Selection of washing chemicals. Environ. Pollution. 144: 2-10. 
Montas, H. J. and A. Shirmohammadi. 2004. Modeling of soil remediation by nanoscale particles. ASAE/CSAE Annual International Meeting. 2004, No. 043053

\section{Rabie, F.H.; M.F. Abdel-Sabour; A.T. Mostafa and S.A. Hassan.} 1999. Enrichment factor of heavy metals in different soil grain size fractions as indicator for soil pollution. Assiut Univ. Bull. Environ. Res. 2 (1) 55-68.

Rabie, F.H. and M.F. Abdel-Sabour. 1999. Studies on Fe, Mn, Ni and $\mathrm{Pb}$ load on soil and its enrichment factor ratios in different soil grain size fractions as an indicator for soil pollution. Assiut Univ. Bull. Environ. Res. 2 (2) 11-23.

Rashad, I.F.; A.O. Abdel Nabi; M.E. El-Hemely and M.A. Khalaf. 1995. Background levels of heavy metals in the Nile Delta soils, Egypt. J. Soil Sci. 35:239-252.

Virkutyte, J.; M. Sillanpaa and P. Latostenmaa. 2002. Electrokinetic soil remediation-critical overview. Sci. Total Environ. 289: 97-121.

Wang, C. and W. Zhang. 1997. Nanoscale metal particles for dechlorination of PCE and PCBs. Environ. Sci. Technol. 31(7): 2154-2156.

Zhang, W. 2003. Nanoscale iron particles for environmental remediation: An overview. J. of Nanoparticle Res. 5: 323-332.

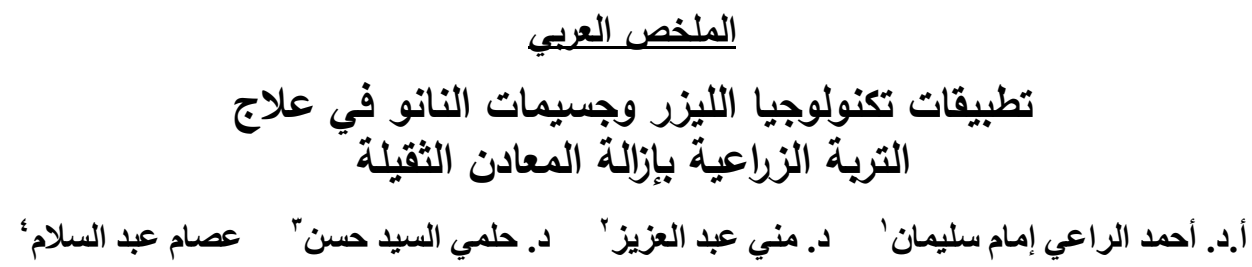

تعتبر التربة المورد الطبيعي الأساسي اللازم لإنتاج أكثر من 9 9 \% من الغذاء العالمي وكذا

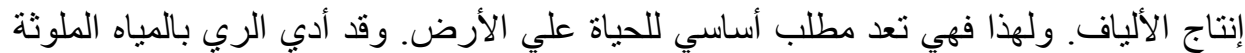

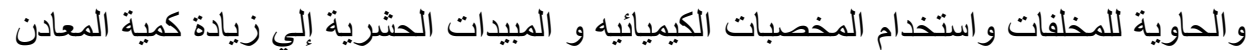
الثقيلة ليتجاوز الحدود القصوى المسموح بها. مما أدي إلي انتقالها للإنسان بواسطة النيات النباتات المزرو عة في تربه ملوثه.

أـ أستاذ الهندسة الزر اعية ـ كلية الزر اعة ـ جامعة القاهرة.

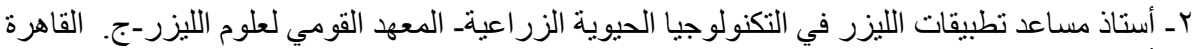

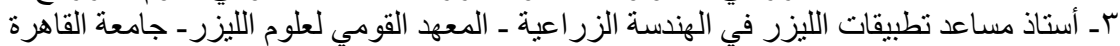
عـ مدرس مساعد- تطبيقات الليزر في الهندسة الزر اعيةـ المعهد القومي لعلوم الليزر - جامعة القاهرة. 
ولذلك أجريت تقنيات عده لإزالة المعادن الثقيلة من التربة مثل الغسيل و التنقية النباتية للتريه والحركة الكهربية. لذا فقد كان الهدف من هذا البحث تحضير جسيمات الحديد النانويه وكذا

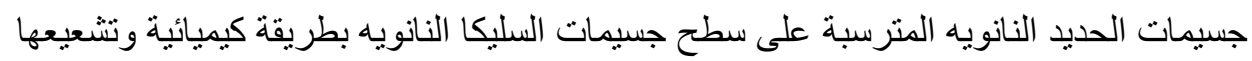
بليزر الأكسيمر النبضي وذللك لإز الة المعادن الثقيلة من التربة. تم إجر اء هذه الدر اسة في المعهد القومي لعلوم الليزر(NILES) بجامعة القاهرة. تم جمع عينات

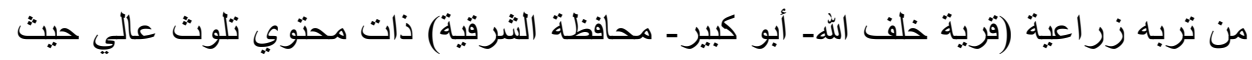

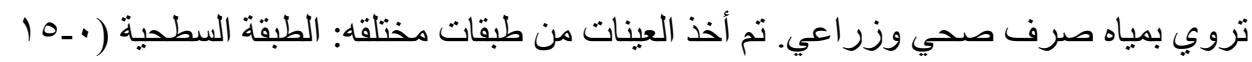

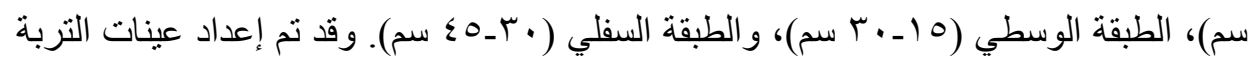

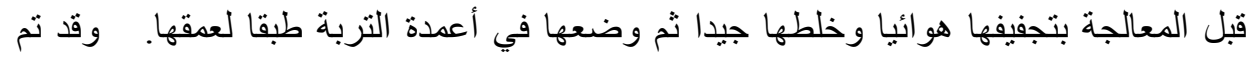

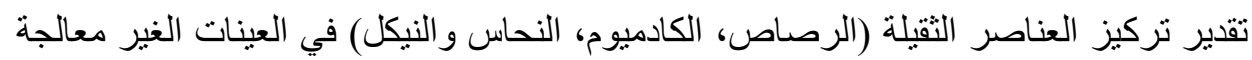

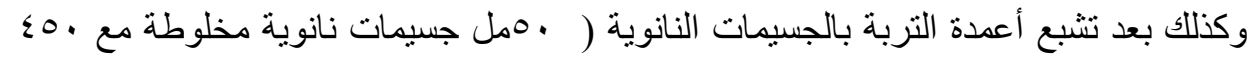

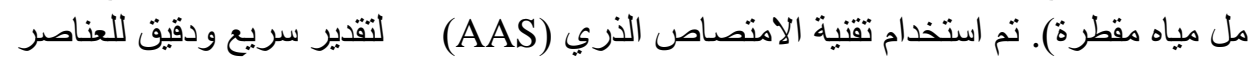
كمياً. كما تم تأكيد النتائج المتحصل عليهاه في المئن المعمل المركزي لتحليل العناصر و النظائر بهيئة الطاقة الذرية. ويمكن تلخيص النتائج المتحصل عليها في هذه الدر اسة كمايلي:

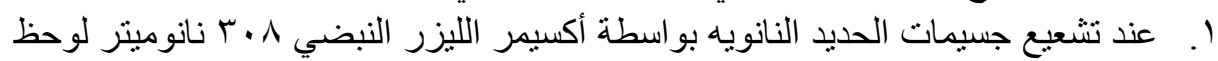

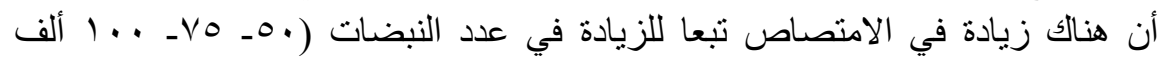

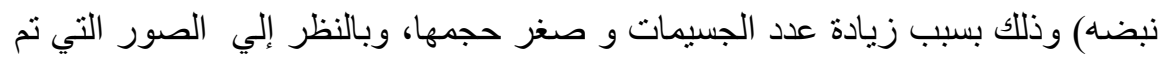
الحصول عليها من الميكروسكوب الالكتروني تبين أنها تصف عملية تصغير الحجم.

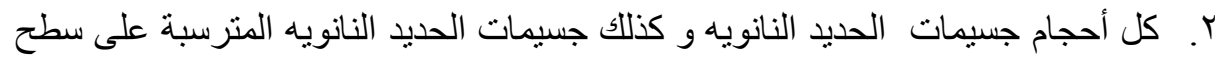
جسيمات السليكا النانويه تعنبر تقنيه جيده فى تنقية التربه من الرصاص و و الكادميوم و ب. . وجد أن كفاءة إز الة المعادن الثقيلة تختلف بين طبقات التربة الثلاثنة وكانت للرصاص

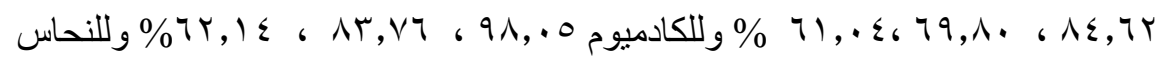
1

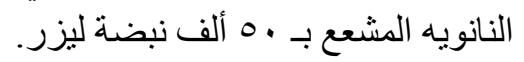

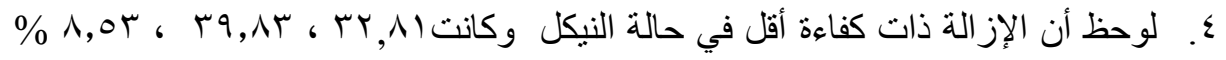
لطبقات التربة الثلاثنة. 